\title{
BREAST ABSCESS; COMPARISON OF RECURRENCE RATE BETWEEN INCISION DRAINAGE AND MULTIPLE NEEDLE ASPIRATION
}

1. MBBS, Medical Officer Basic Health Unit 33 BC, Bahawalpur

2. MBBS, Medical Officer Department of Surgery Bahawal Victoria Hospital, Bahawalpur

3. MBBS, Medical Office Department of Medicine Bahawal Victoria Hospital, Bahawalpur

4. FCPS, FRCS, FACS, MCPS-HPE Professor and Head of Department of Surgery Bahawal Victoria Hospital, Bahawalpur

Correspondence Address:

Dr. Javed lqbal

Professor and Head of Department of Surgery

Bahawal Victoria Hospital,

Bahawalpur

surgeonjaved@hotmail.com

Article received on:

15/10/2016

Accepted for publication:

30/12/2016

Received after proof reading:

$18 / 01 / 2017$

\section{INTRODUCTION}

Breast abscess is commonly seen in lactating women. ${ }^{1}$ Mastitis and proliferation of glandular tissue during lactation are predisposing fectors. ${ }^{2,3}$ Out of total breast diseases, the incidence of breast abscess is $10.2 \%$. 4,5 The commonest presentation is fever, pain, swelling and redness. ${ }^{6}$ Diagnosis is confirmed by ultrasound and aspiration of pus. ${ }^{7}$

Staphylococcus aureus, entering through cracked nipple is the commonest microorgonism. ${ }^{8}$ Breast abscess associated with methicillin-resistant $S$. aureus (MRSA) has also been reported.

The clinical situation demands accurate assessment as early cellulitic phase doesn't require surgery and continued antibiotic therapy in the presence of an abscess may lead local destruction and systemic infection. ${ }^{9}$ Hence the treatment of breast abscess ranges from conservative treatment to surgical intervention. ${ }^{10,11}$
Local measures like breast support and heat fomentation along with antibiotics is the main treatment in the early stage of the disease..$^{12} \mathrm{At}$ the stage of pus formation, the drainage of it is necessary. ${ }^{13}$

The traditional and time tested management of breast abscess is "Incision and Drainage" followed by antibiotics according to culture and sensitivity. ${ }^{14,16}$ This strategy potentially interferes with lactation and associated with poor cosmetic results.

There has been number of reports of treating breast abscesses by repeated aspiration under ultra-sonographic guidance with claims of excellent cosmetic results and less cost. ${ }^{15,17,18,19}$ However the recurrence rate in these studies have been higher than the conventional approach. ${ }^{20}$

Breast abscesses are commonly encountered in our clinical practice. This study has been 
designed to scientifically compare the efficacy of incision and drainage with that of repeated needle aspiration as management of breast abscess. This study is of importance, as the authors could not find any local study addressing this topic. The results of the study may provide evidence to help adopting the technique with better clinical results and less recurrence for the management of this commonly occurring ailment.

\section{OBJECTIVES}

The objective of the study was:

"To compare the recurrence rate between incision drainage and multiple needle aspiration for breast abscess treatment."

\section{OPERATIONAL DEFINITIONS:}

1. Breast abscess: collection of pus in breast tissue diagnosed clinically by presence of all of these i.e. fever ( $>101 \mathrm{~F})$, breast pain and fluctuant (movable and compressible) tender (painful) breast swelling and on ultrasound (ill-defined, central hypo echoic areas with septations and posterior enhancement) was taken as positive.

2. Recurrence: it was measured on $7^{\text {th }}$ day and considered as positive if there will be presence of all of these i.e. fever $(>101 \mathrm{~F})$, breast pain and fluctuant (movable and compressible) tender (painful) breast swelling and on ultrasound (ill-defined, central hypo echoic areas with septations and posterior enhancement), otherwise considered as negative.

\section{MATERIAL AND METHODS}

This randomized controlled trial was conducted under the permission of ethical review committee, in Department of General Surgery, Bahawal Victoria Hospital, Bahawalpur, using Nonprobability, consecutive sampling. The calculated sample size was 60 i.e. 30 cases in each group, with $5 \%$ level of significance, $80 \%$ power of study and taking recurrence rate after incision drainage as $20.0 \%{ }^{20}$ and after multiple needle aspirations as $74.0 \% .{ }^{20}$

All females between the age 20-40 years with breast abscess (as per-operational definition) of $<2 \mathrm{~cm}$ in size and of duration $<2$ weeks were included in the study.

Patients with multiple breast abscesses (assessed on palpation), recurrent breast abscess (assessed on history and medical record). complicated breast abscess (having necrotic patch on skin with underlying malignancy) as assessed on ultrasonography, immune-compromised patients (diabetes mellitus, on chemotherapy as assessed on history and medical record) and unwilling patients were excluded from the study.

\section{DATA COLLECTION PROCEDURE}

A total 60 patients who presented in Department of Surgery, Bahawal Victoria Hospital, Bahawalpur, fulfilling the inclusion/exclusion criteria were selected. After informed, written consent, the patients were randomized into Group A and B, using the lottery method.

In group A patients, incision drainage was done. In group B patients, needle aspiration was done on presentation, day 2 and day 5 if required. All procedures were performed by the same surgeon (with at least 3 years post-fellowship experience). All patients were followed regularly by the researcher for up to 7 days and recurrence (as per-operational definition) was noted. This data was recorded on a specially designed Performa which contained two parts. Part $1^{\text {stincluded the }}$ patient's bio-data while part $2^{\text {nd }}$ contained the study variables i.e. recurrence.

\section{STATISTICAL ANALYSIS}

All the data was entered and analyzed by using SPSS version 20.0. The quantitative variables like age, size of breast abscess and duration of disease were presented as mean and standard deviation. The qualitative variables like parity, marital status (married/unmarried), lactation status (lactating/non-lactating) and recurrence of abscess (yes/no) were presented as frequency and percentage. Chi square was applied to compare the recurrence rate of both groups and $p$-value $\leq 0.05$ was considered as significant. 
Effect modifiers like age, size of breast abscess, duration of disease, parity, marital status (married/ unmarried) and lactation status (lactating/nonlactating) were controlled through stratification and post-stratification chi square was applied to see their effect on recurrence. P-value $\leq 0.05$ was considered as significant.

\section{RESULTS}

Age range in this study was from 20 to 40 years with mean age of $31.23 \pm 5.72$ years. The mean age of patients in group $A$ was $30.83 \pm 5.67$ years and in group $B$ was $31.53 \pm 5.73$ years. Majority of the patients 35 (58.33\%) were between 31 to 40 years of age as shown in Table 1 .

Mean duration of disease was $7.58 \pm 2.83$ days. The mean duration of disease in group $A$ was 7.54 \pm 2.96 days and in group $B$ was $7.76 \pm 2.87$ days. Majority of the patients $36(60.0 \%)$ were between 8-14 days of duration of disease. Mean size of abscess was $0.86 \pm 0.43 \mathrm{~cm}$. The size of abscess in group $A$ was $0.84 \pm 0.36 \mathrm{~cm}$ and in group $B$ was $0.86 \pm 0.47 \mathrm{~cm}$. Majority of the patients 31 $(51.67 \%)$ were $\leq 1 \mathrm{~cm}$ of size of abscess.

Percentage of patients according to parity is shown in Table I; women with 0-2 children had a p-value of 0.001 and those with 3-4 children had that of 0.058 (Table I). 21 (35.00\%) patients were unmarried whereas $39(65.00 \%)$ patients were married (Table I). Off the total women, 19(31.67\%) were lactating and $41(68.33 \%)$ were non-lactating (Table I).

Recurrence was found in 07 (23.33\%) patients in group A (incision drainage) while in 21 (70.0\%) patients in group $\mathrm{B}$ (multiple needle aspiration) with p-value of 0.000 which is statistically significant (Figure 1).

Stratification of recurrence with respect to age groups, duration of disease, size of abscess, parity, marital status and lactation is collectively shown in Table I.

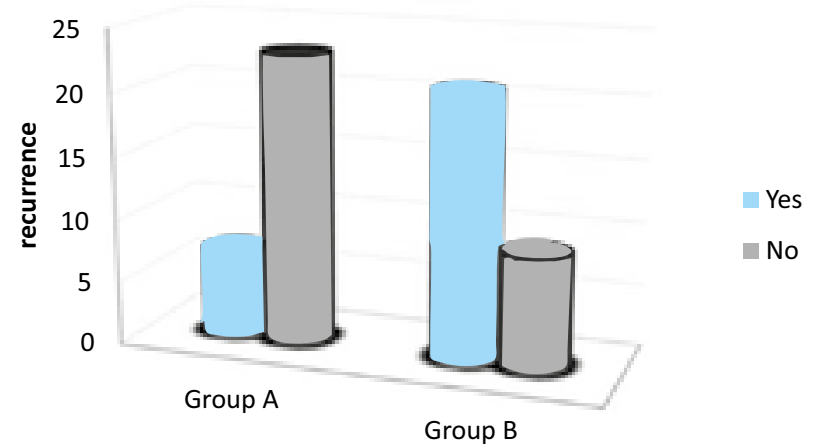

Figure-1. Percentage of patients with recurrence in both groups

P-value $=0.000$ which is statistically significant

\begin{tabular}{|c|c|c|c|c|c|c|}
\hline \multirow{3}{*}{ Factors studied } & & \multirow{2}{*}{\multicolumn{2}{|c|}{$\begin{array}{c}\text { Group A }(n=30) \\
\text { Recurrence }\end{array}$}} & \multirow{2}{*}{\multicolumn{2}{|c|}{$\begin{array}{c}\text { Group B }(n=30) \\
\text { Recurrence }\end{array}$}} & \multirow{3}{*}{ P-value } \\
\hline & & & & & & \\
\hline & & yes & no & yes & no & \\
\hline \multirow{2}{*}{ Age in years } & $20-30$ & $02(15.38 \%)$ & 11 (84.62\%) & $06(50.0 \%)$ & $06(50.0 \%)$ & 0.064 \\
\hline & $31-40$ & 05 (29.41\%) & 12 (70.59\%) & $15(83.33 \%)$ & 03 (16.67\%) & 0.001 \\
\hline \multirow{2}{*}{$\begin{array}{l}\text { Duration of } \\
\text { disease }\end{array}$} & $1-7$ days & 01 (9.09\%) & 10 (90.91\%) & 10 (76.92\%) & 03 (23.08\%) & 0.001 \\
\hline & 8-14 days & $06(31.58 \%)$ & $13(68.42 \%)$ & $11(64.71 \%)$ & 06 (35.29\%) & 0.047 \\
\hline \multirow[t]{2}{*}{ Size of abscess } & $\leq 1 \mathrm{~cm}$ & 02 (12.50\%) & $14(87.50 \%)$ & $12(80.0 \%)$ & $03(20.0 \%)$ & 0.000 \\
\hline & $>1 \mathrm{~cm}$ & 05 (35.71\%) & 09 (64.29\%) & 09 (60.0\%) & $06(40.0 \%)$ & 0.191 \\
\hline \multirow{2}{*}{ Parity } & $0-2$ & 03 (18.75\%) & $13(81.25 \%)$ & $12(75.0 \%)$ & $04(25.0 \%)$ & 0.001 \\
\hline & $3-4$ & $04(28.57 \%)$ & $10(71.43 \%)$ & 09 (64.29\%) & 05 (35.71\%) & 0.058 \\
\hline \multirow{2}{*}{ Marital status } & Married & 04 (21.05\%) & 15 (78.95\%) & 15 (75.0\%) & $05(25.0 \%)$ & 0.001 \\
\hline & Unmarried & $03(27.27 \%)$ & 08 (72.73\%) & $06(60.0 \%)$ & $04(40.0 \%)$ & 0.130 \\
\hline \multirow{2}{*}{ Lactation status } & Lactating & $02(22.22 \%)$ & 07 (77.78\%) & $07(70.0 \%)$ & 03 (30.0\%) & 0.037 \\
\hline & Non-lactating & 05 (23.81\%) & 16 (76.19\%) & $14(70.0 \%)$ & 06 (30.0\%) & 0.003 \\
\hline
\end{tabular}




\section{DISCUSSION}

Treatment of breast abscesses is a demanding clinical problem. The classical treatment of breast abscess is incision and drainage under general anesthesia. The cavity is packed with gauze and kept open with subsequent dressing changes for up to 6 weeks till wound heals through granulation. ${ }^{10}$ Cosmetic results are usually not good due to scar formation. The recurrence rate even with this aggressive approach is between $10 \%$ and $38 \%{ }^{21}$

Ultrasonographyisfound to be effectiveindetecting abscesses in patients with mastitis ${ }^{22}$ and to guide for needle aspiration of the abscess. A study from Scandinavia ${ }^{23}$ showed the management of breast abscesses using the same technique as applied for sub-cutaneous abscesses using polyethylene pigtail catheters, with good cosmetic results and no abscess recurrences. The group reported a similar study with more number of patients, after three years with similar results..$^{24}$ In a similar study from Britin, ${ }^{25}$ blind needle aspiration of breast abscesses without an pigtail catheter was evaluated. The study showed that repeated attempts of aspirations are required before complete healing, if cather in not placed in.

In our study, recurrence was found in 07 (23.33\%) patients in group A (incision drainage) while in $21(70.0 \%)$ patients in group B (multiple needle aspiration) with $p$-value of 0.000 which is statistically significant. These results are comparable with a similar randomized controlled trial by Gaspari RJ et al. ${ }^{20}$

Studies by Garg et $\mathrm{al}^{26}$ Faisal Elagili et $\mathrm{al}^{27}$ and Alphonce et $\mathrm{al}^{28}$ reported recurrence rate of $44 \%, 33.3 \%$ and $93.1 \%$ respectively. In our study recurrence rate of $70.0 \%$ in the group managed by repeated aspiration co-related with studies which correlates with similar studies by Markuset al. ${ }^{29}$ and Srauss et al. ${ }^{30}$

The literature support the placement of suction drainage catheter in breast abscess for 3-7 days when incision and drainage is not done by open method. It is effective, results in better cosmetic yield and is without any complication. The breast feeding may be continued with catheter in the cavity. Large abscesses require suction catheter rather than ordinary drains. ${ }^{31,32}$

We share the findings of Sharma who emphasized in use of early ultrasonography for breast abscess so that proper strategy can be formulated. ${ }^{33}$

Although there are reports of better cosmetic results yet despite of many studies using repeated aspiration as management of breast abscess, our study produced an evidence against repeated aspiration of breast abscess as a preferred strategy over standard incision and drainage. This is mainly because of higher incidence of recurrence in the group treated with repeated aspiration as compared to those treated by incision and drainage. The higher recurrence rate overweighs the perceived cosmetic advantages. Our argument is supported by similar studies conducted at various centers ${ }^{26-30}$.

\section{CONCLUSION}

This study concluded that the recurrence rate is less after incision drainage for treating breast abscess compared to multiple needle aspirations. We therefore advocate the incision and drainage as a preferred strategy to manage the breast abscesses.

Copyright@ 30 Dec, 2016.

\section{REFERENCES}

1. Afridi SP, Alam SN, Ainuddin S. Aspiration of breast abscess through wide bore14-gauge intravenous cannula. J Coll Physicians Surg Pak. 2014;24(10):71921.

2. Hagiya H, Shiota S, Sugiyama W, Otsuka F. Postpartum breast abscess caused by community-acquired methicillin-resistant Staphylococcus aureus in Japan. Breastfeed Med. 2014;9:45-6.

3. Leibman AJ, Misra M, Castaldi M. Breast abscess after nipple piercing: sonographic findings with clinical correlation. J Ultrasound Med. 2011;30:1303-8.

4. Jamal S, Khaliq T, Shabbir S. The frequency of various causes of breast lumps in females presenting to surgical OPD in a tertiary care hospital. Ann Pak Inst Med Sci. 2013;9:26-9. 
5. Kandi AJ, Gite VA, Varudkar AS. Management of breast abscess by ultrasound guided needle aspiration against incision and drainage. Int MedJ.2014;1(10):655-59.

6. King TA, Morrow M. Breast disease In: Mulhouand MW, Lillemoe KD, Doherty GM, Maier RV, Simeone DM. Greenfield's Surgery-scientific principles \& practice. 5th ed. Philadelphia: lippincott Williams \& Wilkins; 2011. p. 1241-81.

7. Suthar KD, Mewada BN, Surati KN, Shah JK. Comparison of percutaneous ultrasound guided needle aspiration and open surgical drainage in management of puerperal breast abscess. Int $\mathrm{J}$ Med Sci Public Health. 2013;2:69-72.

8. Benson EA, Goodman MA. Incision with primary suture in the treatment of acute puerperal breast abscess. Br J Surg. 1970;57(1):55-58.

9. Taylor MD, Way S. Penicillin in treatment of acute puerperal mastitis. Br Med J. 1946;2(4480):731.

10. Osterman $\mathrm{KL}$, Rahm VA. Lactation mastitis: bacterial cultivation of breast milk, symptoms, treatment, and outcome. J Hum Lact. 2000;16(4):297-302.

11. Hunt KK, Newman LA, Copeland EM, Bland KI. The breast In: Bruncardi FC, Andersen DK, Billiar TR, Dunn DL, Hunter JG, Matthews JB, et al. Schwartz's principles of surgery. 9th ed. NewYork, USA: The McGraw-Hill Companies; 2010. p. 423-74.

12. Newnham MS, Brown $H$, Martin AC, Plummer JM, Mitchell DIG, Cawich SO. Management of breast abscesses in jamaican women: is there need for a paradigm shift? West Indian Med J. 2012;61(3):245-48.

13. Chandika BA, Gakwaya MA, MalwaddeKE, Chalya LP. Ultrasound guided needle aspiration versus surgical drainage in the management of breast abscesses: a ugandan experience. BMC Res Notes. 2012;5:12.

14. Jones NA. Wilson $\mathrm{DH}$. The treatment of acute abscesses by incision, curettage and primary suture under antibiotic cover. Br J Surg. 1976;63(6):499-501.

15. Abraham N, Doudle M, Carson P. Open versus closed surgical treatment of abscesses: a controlled clinical trial. Aust N Z J Surg. 1997;67(4):173-176.

16. Bhishagratna KK. English translation of Sushruta Samhita (ca 600 B.C.). Calcutta: Bose, 1916.

17. Imperiale A, Zandrino F, Calabrese M, Parodi G, MassaT. Abscesses of the breast: US-guided serialpercutaneous aspiration and local antibiotic therapy afterunsuccessful systemic antibiotic therapy. ActaRadiol. 2001;42(2):161-165.

18. Barclay L, Lie D. Ultrasound Useful for Treatment of Breast Abscess. Radiology. 2004;232:904-909.

19. Sarhan $\mathrm{HH}$, Ibraheem MO. Percutaneous needle aspiration is a minimally invasive method for a breast abscess. Arch Clin Exp Surg. 2012;1:105-9.

20. Gaspari RJ, Resop D, Mendoza M, Kang T, Blehar D. A randomized controlled trial of incision and drainage versusultrasonographically guided needle aspiration for skin abscesses and the effect of methicillin-resistant staphylococcus aureus. Ann Emerg Med. 2011;57:48391.

21. Watt-Boolsen S, Rassmussen NR, Bilchert-Toft M. Primary periareolar abscess in the nonlactating breast: risk of recurrence. Am J Surg 1987; 153:571573.

22. Crowe DJ, Helvie MA, Wilson TE. Breast infection: mammographic and sonographic findings with clinical correlation. Invest Radiol 1995; 30:582-587.

23. Karstrup S, Nolsoe C, Brabrand K, Nielsen $\mathrm{KR}$. Ultrasonically guided percutaneous drainage of breast abscesses. Acta Radiol1990; 31:157-159.

24. Karstrup S, Solvig J, Nolsoe CP, et al. Acute puerperal breast abscesses: US-guided drainage. Radiology 1993; 188:807-809.

25. Dixon JM. Outpatient treatment of non-lactational breast abscesses. Br J Surg 1992; 79:56-57.

26. Garg P, Rathee SK, Lal A. Ultrasonically guided percutaneous drainage of breast abscess. J Indian Med Assoc 1997; $95: 584-5$.

27. Elagili F, Adbullah N, Fong L, Pei T. Aspiration of breast abscess under ultrasound guidance: outcome obtained and factors affecting success. Asian J Surg. 2007;30(1):40-44.

28. Chandika AB, Gakwaya AM, Kiguli-Malwadde E, Chalya PL. Ultrasound guided needle aspiration versus surgical drainage in the management of breast abscesses: a ugndan experience. 2012.

29. Fahrni M. Breast abscesses: diagnosis, treatment and outcome. 2012.

30. Srauss. Sonoghraphically guided percutaneous needle aspiration of breast abscesses-a minimal invasive alternative to surgical incision. Ultraschall Med 2003;24(6):393-398.

31. Schwarz RJ, Shrestha R. Needle aspiration of breast 
abscesses. Am J Surg. 2001;182(2):117-119.

32. Tewari M, Shukla HS. Effective method of drainage of puerperal breast abscess by percutaneous placement of suction drain. Indian J Surg. 2006;68(6):330-333.
33. Sharma R. Drainage of puerperal breast abscess by percutaneous placement of suction drain should not be popularized as a novel surgical technique outside carefully controlled trials. Indian J Surg. 2007;69(1):33.

\title{
PREVIOUS RELATED STUDY
}

Saira Saleem, Tariq Farooq, Naeemullah Khan, Muhammad Shafiq, Muhammad Azeem, Riaz Hussain Dab. PUERPERAL BREAST ABSCESSES; PERCUTANEOUS ULTRASOUND GUIDED DRAINAGE COMPARED WITH CONVENTIONAL INCISION AND DRAINAGE. (Original) Prof Med Jour 15(4) 431-436 Oct, Nov, Dec, 2008.

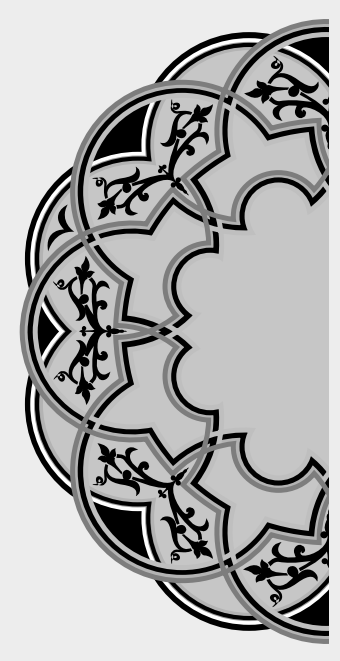

\section{"A friend is someone who knows all about you and still loves you."}

\author{
Elbert Hubbard
}

\section{AUTHORSHIP AND CONTRIBUTION DECLARATION}

\begin{tabular}{|c|c|c|c|}
\hline Sr. \# & Author-s Full Name & Contribution to the paper & Author $=$ s Signature \\
\hline 1 & Dr. M. Umar Javed & $\begin{array}{l}\text { Compiled the data and did } \\
\text { drafting }\end{array}$ & tos \\
\hline 2 & Dr. Sidra Aleem & Conducted the study & \\
\hline 3 & Dr. Sheraz Jamil Asif & do & \\
\hline 4 & Dr. Javed Iqbal & Supervised the study & \\
\hline
\end{tabular}

